\title{
REVIEW
}

\section{Management of anticoagulant-related intracranial hemorrhage: an evidence-based review}

\author{
Bappaditya Ray ${ }^{1 *}$ and Salah G Keyrouz ${ }^{2}$
}

\begin{abstract}
The increased use of anticoagulants for the prevention and treatment of thromboembolic diseases has led to a rising incidence of anticoagulant-related intracranial hemorrhage $(\mathrm{AICH})$ in the aging western population. High mortality accompanies this form of hemorrhagic stroke, and significant and debilitating long-term consequences plague survivors. Although management guidelines for such hemorrhages are available for the older generation anticoagulants, they are still lacking for newer agents, which are becoming popular among physicians. Supportive care, including blood pressure control, and reversal of anticoagulation remain the cornerstone of acute management of $\mathrm{AlCH}$. Prothrombin complex concentrates are gaining popularity over fresh frozen plasma, and reversal agents for newer anticoagulation agents are being developed. Surgical interventions are options fraught with complications, and are decided on a case-by-case basis. Our current state of understanding of this condition and its management is insufficient. This deficit calls for more population-based studies and therapeutic trials to better evaluate risk factors for, and to prevent and treat $\mathrm{AlCH}$.
\end{abstract}

\section{Introduction}

Use of anticoagulation therapy among the older western population for varied thromboembolic diseases potentially places them at risk of developing anticoagulant-related intracranial hemorrhage (AICH). The indications for use of anticoagulants are published in a guideline statement by the American College of Chest Physicians [1], to which readers are referred. AICH can be spontaneous or traumatic, and can occur in different intracranial compartments (for example, subdural hemorrhage, epidural hemorrhage,

\footnotetext{
* Correspondence: Bappaditya-Ray@ouhsc.edu

'Division of Critical Care Neurology, Department of Neurology, The University of Oklahoma Health Sciences Center, 920 Stanton L Young Blvd, Ste 2040, Oklahoma City, OK 73104, USA

Full list of author information is available at the end of the article
}

subarachnoid hemorrhage, or intracerebral hemorrhage (ICH)). Most clinical data on AICH are related to ICH, while extraparenchymal hemorrhages are reported but data on these are sparse.

In the absence of clinical evidence, definitive guidelines, and proven therapies, clinicians are left scrambling for rapid correction of the coagulopathy and maintaining homeostasis to prevent secondary brain injury. The basic pharmacological properties of commonly used anticoagulants, their mechanism of action, and their indications are presented in Table 1 and Figure 1. Interested readers are referred to recently published articles for in-depth reviews of these agents [2,3]. The present review will primarily focus on the importance and impact of $\mathrm{AICH}$, and, where available, the evidence-based management of this mostly iatrogenic disease.

\section{Epidemiology}

The use of anticoagulants has increased exponentially over the last two decades along with the incidence of atrial fibrillation in aging western populations [4-6]; 5.6 million patients in the USA will be on anticoagulation for atrial fibrillation by 2050 [7]. With this increased use, the incidence of $\mathrm{AICH}$ has risen; the Greater Cincinnati area has seen a threefold increase in incidence during a 10-year period [8]. It is unclear whether a similar trend is still persistent with the introduction of newer generation oral anticoagulants (see below). Warfarin - the most commonly used, and therefore most extensively studied, long-term oral anticoagulant - is responsible for 9 to $14 \%$ of ICH [9-11] and carries 0.3 to $3.7 \%$ annual risk of warfarin-related intracerebral hemorrhage (WRICH) when the International Normalized Ratio (INR) is between 2 and 4.5 [12]. The risk of ICH in patients on long-term anticoagulation is 8 to 11 times higher than that of age-matched cohorts not taking anticoagulants $[13,14]$. Advanced age ( $\geq 70$ years) $[15,16]$, hypertension $[9,14,15,17]$ and concurrent use of single or dual antiplatelets [18] are risk factors for WRICH. Other established risk factors include the early period after warfarin 
Table 1 Pharmacologic properties of anticoagulants

\begin{tabular}{|c|c|c|c|c|c|c|c|c|c|}
\hline Drug & Target & $\begin{array}{l}\text { Antithrombin } \\
\text { dependent }\end{array}$ & Route & Half-life (hours) & $\begin{array}{l}\text { Protein } \\
\text { binding }\end{array}$ & Renal excretion & Monitoring & Antidote & Common indications \\
\hline Warfarin & $\begin{array}{l}\text { Factors II, VIII, IX, X; } \\
\text { proteins C, S }\end{array}$ & No & p.o. & 30 to 40 & $99 \%$ & $92 \%$ & INR & Vitamin $\mathrm{K}$ & $\begin{array}{l}\text { Thromboembolic prophylaxis in } \\
\text { AF. Treatment of VTE. Thrombosis } \\
\text { prophylaxis in prosthetic valve }\end{array}$ \\
\hline UFH & $\begin{array}{l}\text { Factors II, Xa } \\
\text { (VIla, IXa, Xla, XIla) }\end{array}$ & Yes & i.v., s.c. & $\begin{array}{l}0.5 \text { to } 2.5 \\
\text { (dose dependent) }\end{array}$ & Variable & $\begin{array}{l}\text { Mostly after } \\
\text { hepatic metabolism }\end{array}$ & aPTT & Protamine sulfate & $\begin{array}{l}\text { ACS. Thromboprophylaxis. } \\
\text { Thromboembolic diseases } \\
\text { (including ischemic stroke, } \\
\text { CVST) in acute phase }\end{array}$ \\
\hline LMWH & Factors Ila, Xa & Yes & S.C., i.v. & $\begin{array}{l}\text { Variable according } \\
\text { to the product }\end{array}$ & Variable & $\begin{array}{l}40 \%(10 \% \\
\text { unchanged) }\end{array}$ & Anti-factor Xa & $\begin{array}{l}\text { Protamine } \\
\text { sulfate (60\%) }\end{array}$ & $\begin{array}{l}\text { ACS. Thromboprophylaxis. } \\
\text { Thromboembolic diseases }\end{array}$ \\
\hline Fondaparinux & Factor Xa & Yes & s.c. & 17 to 21 & $94 \%$ & $\begin{array}{l}\sim 100 \%(77 \% \\
\text { unchanged) }\end{array}$ & Anti-factor Xa & None (see text) & $\begin{array}{l}\text { VTE. Thromboprophylaxis. Selected } \\
\text { cases of HIT }\end{array}$ \\
\hline Argatroban & Factor Ila & No & i.v. & $\begin{array}{l}0.75 \text { (prolonged in } \\
\text { hepatic dysfunction) }\end{array}$ & $54 \%$ & $\begin{array}{l}22 \%(16 \% \\
\text { unchanged) }\end{array}$ & aPTT, ACT & None & $\begin{array}{l}\text { HIT. Thromboprophylaxis in } \\
\text { patients suspected of HIT. ACS }\end{array}$ \\
\hline Bivalirudin & Factor lla & No & i.v. & $\begin{array}{l}0.5 \text { (prolonged in } \\
\text { renal impairment) }\end{array}$ & $\begin{array}{l}\text { Only to } \\
\text { factor } \\
\text { Ila }\end{array}$ & $20 \%$ unchanged & $\begin{array}{l}\mathrm{ECT}(\mathrm{PT}, \mathrm{PPTT}, \mathrm{ACT} \text { has } \\
\text { nonlinear prolongation) }\end{array}$ & None & $\begin{array}{l}\text { HIT. ACS after thrombolysis. } \\
\text { Thromboembolic prophylaxis } \\
\text { during interventional procedures }\end{array}$ \\
\hline Dabigatran & Factor lla & No & p.o. & 12 to 14 & $35 \%$ & $80 \%$ & $\begin{array}{l}\text { Modified TT/ECT/anti- } \\
\text { factor Ila (also see Table 3) }\end{array}$ & $\begin{array}{l}\mathrm{PCC} / \mathrm{FEIBA}^{\mathrm{TM}} / \mathrm{rFVlla} \\
\text { (see text) }\end{array}$ & $\begin{array}{l}\text { Thromboembolic prophylaxis in AF. } \\
\text { Treatment and thromboprophylaxis } \\
\text { of VTE }\end{array}$ \\
\hline Apixaban & Factor Xa & No & p.o. & 8 to 14 & $87 \%$ & $\sim 25 \%$ & $\begin{array}{l}\text { Anti-factor Xa } \\
\text { (also see Table 3) }\end{array}$ & $\begin{array}{l}\mathrm{PCC} / \mathrm{FEIBA}^{\mathrm{TM}} / \mathrm{rFV} \text { Ila } \\
\text { (see text) }\end{array}$ & $\begin{array}{l}\text { Thromboembolic prophylaxis in AF. } \\
\text { Treatment and thromboprophylaxis } \\
\text { of VTE }\end{array}$ \\
\hline Rivaroxaban & Factor Xa & No & p.o. & 7 to 11 & $93 \%$ & $\begin{array}{l}66 \%(33 \% \\
\text { unchanged) }\end{array}$ & $\begin{array}{l}\text { Anti-factor Xa } \\
\text { (also see Table 3) }\end{array}$ & $\begin{array}{l}\mathrm{PCC} / \mathrm{FEIBA}^{\mathrm{TM}} / \mathrm{rFV} \text { Ila } \\
\text { (see text) }\end{array}$ & $\begin{array}{l}\text { Thromboembolic prophylaxis in AF. } \\
\text { Treatment and thromboprophylaxis } \\
\text { of VTE }\end{array}$ \\
\hline
\end{tabular}

ACS, acute coronary syndrome; ACT, activated clotting time; AF, atrial fibrillation; aPTT, activated partial thromboplastin time; CVST, cerebral venous sinus thrombosis; ECT, ecarin clotting time; HIT, heparin-induced thrombocytopenia; INR, International Normalized Ratio; i.v., intravenous; LMWH, low molecular weight heparin; PCC, prothrombin complex concentrate; p.o., per oral; PT, prothrombin time; rFVIlla, activated recombinant factor VII; s.c., subcutaneous; $\Pi$, thrombin time; UFH, unfractionated heparin; VTE, venous thromboembolism. FEIBA ${ }^{\text {Tm }}$ from Baxter (Deerfield, IL, USA). 


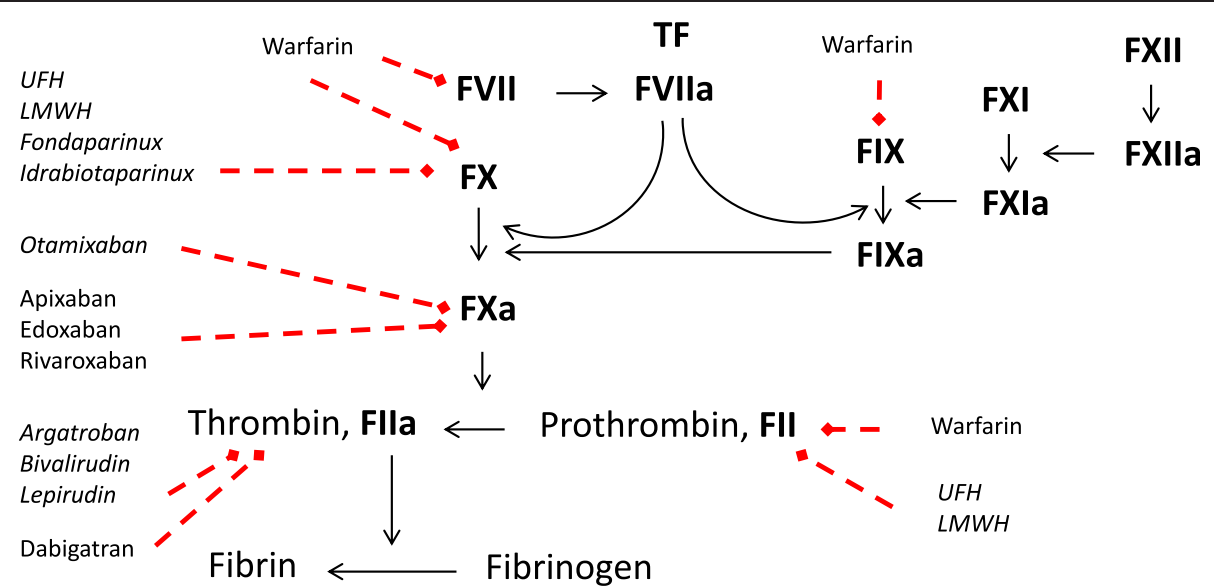

Figure 1 Clinically available anticoagulants and their sites of action. Dashed red arrows, sites of action. Italicized drugs are for parenteral use. F, factor; LMWH, low molecular weight heparin; TF, tissue factor; UFH, unfractionated heparin.

initiation $[9,13,19]$, supratherapeutic levels of anticoagulation $[9,14,17,20-23]$ and associated leukoaraiosis [21,23].

Similarly, unfractionated heparin (UFH) - a parenteral anticoagulant for various indications - also carries a risk of $\mathrm{AICH}$. The incidence of symptomatic ICH used with UFH or heparinoids is 1 to $2.7 \%$ in patients with acute ischemic stroke $[24,25]$. A direct thrombin inhibitor, argatroban, another commonly used short-term parenteral anticoagulant, is associated with a $4.3 \%$ incidence of AICH [26].

In contrast, there are promising yet limited clinical data on AICH associated with the use of newer oral anticoagulants. The results of recent clinical trials using these drugs are presented in Table 2. The rates of ICH were $0.74 \%$, $0.30 \%$, and $0.23 \%$ per year among those assigned to warfarin, dabigatran $150 \mathrm{mg}$, and dabigatran $110 \mathrm{mg}$ respectively in the RE-LY (Randomized Evaluation of Long Term Anticoagulant Therapy) trial, which assessed the efficacy of this oral direct thrombin inhibitor in atrial fibrillation [27]. In contrast, in the RE-COVER (Efficacy and Safety of Dabigatran Compared to Warfarin for 6 Month Treatment of Acute Symptomatic Venous Thromboembolism) trial, which compared dabigatran and warfarin in acute venous thromboembolism, there were no incidences of $\mathrm{ICH}$ during 6 months of therapy [28]. The yearly incidence of AICH ranged between 0.33 and $0.35 \%$ for apixaban, an oral factor Xa inhibitor, in two different trials - the ARISTOTLE (Apixaban for Reduction in Stroke and Other Thromboembolic Events) trial and the AVERROES (Apixaban Versus Acetylsalicylic Acid to Prevent Strokes) trial $[29,30]$. The incidence of AICH linked to rivaroxaban, another oral factor $\mathrm{Xa}$ inhibitor, in the ROCKET-AF (Rivaroxaban Once-daily Oral Direct Factor Xa Inhibition Compared with Vitamin K Antagonism for Prevention of Stroke and Embolism Trial in Atrial Fibrillation) study was $0.49 \%$; that of warfarin was 0.74\% $(P<0.05)[31]$. However, in the EINSTEIN-PE (Oral Rivaroxaban Alone for the Treatment of Symptomatic
Pulmonary Embolism) trial - a study that compared the efficacy of rivaroxaban with that of enoxaparin followed by warfarin in patients with pulmonary embolism - the incidence of AICH was lower for rivaroxaban $(0.1 \%$ vs. $0.5 \%$; $P=0.003$ ) [32]. For cerebrovascular indication, national registry data showed similar peri-procedural incidence of ICH with bivalirudin and UFH after carotid stenting $(0.1 \%$ vs. $0.2 \%$; odds ratio $=0.62,95 \%$ confidence interval $=0.20$ to $1.91 ; P=0.41$ ) [33].

Outcomes after AICH have been mostly studied in patients on warfarin. Patients with WRICH fare worse than those with ICH without coagulopathy, with case fatality rates ranging between 44 and 68\% [34-36]. In the Greater Cincinnati study, patients on warfarin with INR $>3.0$ had larger hematomas than other patients [37]. After presentation, hematoma enlargement is more common and could still occur beyond the first 24 hours in anticoagulated patients [37-39]. What is more worrisome is that hematoma could still expand despite rapid correction of coagulopathy [40]. Little is known about the outcome of patients with $\mathrm{AICH}$ related to the newer anticoagulants; however, with an expected rise in use as they get wider acceptance [41], physicians on the forefront are likely to encounter more patients with such hemorrhages.

\section{Management}

There are several uncertainties in the management of $\mathrm{AICH}$. These uncertainties include the lack of evidence and limited guidelines for using biological products and pharmacologic agents, and accurate, quick, and meaningful laboratory testing to evaluate the hemostatic system. Moreover, individual variation in response to therapy and the difficulty in assessing ongoing bleeding make it even more challenging to manage this clinical problem [42]. One should also note that the mere correction of a laboratory parameter (that is, an ex vivo test) might not correlate with 
Table 2 Intracranial hemorrhage rates reported in phase 3 clinical trials of dabigatran, rivaroxaban and apixaban related to stroke prevention and treatment of acute venous thromboembolism

\begin{tabular}{|c|c|c|c|c|c|}
\hline Clinical trial & Indication & Inclusion criteria & Drug & Primary outcome & Intracranial bleeding \\
\hline$\overline{R E-L Y}$ & $\begin{array}{l}\text { Stroke } \\
\text { prevention in } \\
\text { nonvalvular atrial } \\
\text { fibrillation }\end{array}$ & $\begin{array}{l}\text { AF patients with moderate to high } \\
\text { risk of stroke or systemic embolism } \\
\text { with at least one of the following: } \\
\text { age }>75 \text { years; h/o TIA or stroke; } \\
\text { LVEF < }<40 \% \text {; NYHA class II or higher; } \\
\text { age } 65 \text { to } 74 \text { years with either DM, } \\
\text { CAD, hypertension }\end{array}$ & $\begin{array}{l}\text { Dabigatran } 110 \mathrm{mg} \text { or } 150 \mathrm{mg} \text { BID; } \\
\text { warfarin with target INR } 2 \text { to } 3\end{array}$ & $\begin{array}{l}\text { Prevention of stroke/systemic } \\
\text { embolism: dabigatran } 110 \mathrm{mg} \\
1.54 \% / \text { year; dabigatran } 150 \mathrm{mg} \\
1.11 \% / \text { year; warfarin, } 1.71 \% / \text { year }\end{array}$ & $\begin{array}{l}\text { AICH: dabigatran } 110 \mathrm{mg}, 0.23 \% / \text { year; } \\
\text { dabigatran } 150 \mathrm{mg}, 0.30 \% / \text { year }(P<0.05) \text {; } \\
\text { warfarin, } 0.74 \% / \text { year }\end{array}$ \\
\hline ROCKET-AF & $\begin{array}{l}\text { Stroke } \\
\text { prevention in } \\
\text { nonvalvular atrial } \\
\text { fibrillation }\end{array}$ & $\begin{array}{l}\text { AF with history of stroke or TIA. } \\
\text { AF with two or more of the following: } \\
\text { symptomatic heart failure or } \\
\text { LVEF }<35 \% \text {; age }>75 \text { years; DM }\end{array}$ & $\begin{array}{l}\text { Rivaroxaban } 20 \mathrm{mg} \text { daily; warfarin } \\
\text { with target INR } 2 \text { to } 3\end{array}$ & $\begin{array}{l}\text { Prevention of stroke/systemic } \\
\text { embolism: rivaroxaban, } 2.12 \% / \\
\text { year; warfarin, } 2.42 \% / \text { year }\end{array}$ & $\begin{array}{l}\text { AICH (all): rivaroxaban, } 0.49 \% / y e a r \\
(P<0.05) \text {; warfarin, } 0.74 \% / y e a r . ~ I C H: \\
\text { rivaroxaban, } 0.33 \% / \text { year; warfarin, } \\
0.49 \% / \text { year. SDH: rivaroxaban, 0.13\%/year; } \\
\text { warfarin, } 0.27 \% / \text { year }\end{array}$ \\
\hline ARISTOTLE & $\begin{array}{l}\text { Stroke } \\
\text { prevention in } \\
\text { nonvalvular atrial } \\
\text { fibrillation }\end{array}$ & $\begin{array}{l}\text { AF with one or more of following: } \\
\text { TIA or systemic embolism; symptomatic } \\
\text { CHF or LVEF } \leq 40 \% \text {; DM or hypertension } \\
\text { on pharmacological treatment }\end{array}$ & $\begin{array}{l}\text { Apixaban } 5 \mathrm{mg} \text { BID; warfarin with } \\
\text { target INR } 2 \text { to } 3\end{array}$ & $\begin{array}{l}\text { Prevention of stroke/systemic } \\
\text { embolism: apixaban, 1.27\%/year; } \\
\text { warfarin, 1.60\%/year }\end{array}$ & $\begin{array}{l}\text { AlCH: apixaban, 0.33\%/year; warfarin, } \\
0.80 \% / \text { year }\end{array}$ \\
\hline RE-COVER & $\begin{array}{l}\text { VTE recurrence } \\
\text { prevention }\end{array}$ & Acute symptomatic DVT of legs or PE & $\begin{array}{l}\text { Dabigatran } 150 \mathrm{mg} \text { BID; warfarin } \\
\text { with target INR } 2 \text { to } 3\end{array}$ & $\begin{array}{l}\text { Thromboembolism or related } \\
\text { deaths: dabigatran, } 2.4 \% \text {; } \\
\text { warfarin, } 2.1 \%\end{array}$ & AlCH: dabigatran, 0; warfarin, $0.24 \%$ \\
\hline RECOVER II & $\begin{array}{l}\text { VTE recurrence } \\
\text { prevention }\end{array}$ & Acute symptomatic DVT of legs or PE & $\begin{array}{l}\text { Dabigatran } 150 \mathrm{mg} \text { BID; heparin/enoxaparin } \\
\text { followed by warfarin with target INR } 2 \text { to } 3\end{array}$ & $\begin{array}{l}\text { Recurrent VTE: dabigatran, } \\
\text { 2.3\%; warfarin, } 2.2 \%\end{array}$ & Not reported \\
\hline EINSTEIN-DVT & $\begin{array}{l}\text { Prevention of } \\
\text { VTE recurrence }\end{array}$ & Acute symptomatic DVT & $\begin{array}{l}\text { Rivaroxaban } 15 \mathrm{mg} \text { BID } \times 3 \text { weeks followed } \\
\text { by } 20 \mathrm{mg} \text { daily. Standard therapy: enoxaparin } \\
1 \mathrm{mg} / \mathrm{kg} \text { BID; bridging warfarin or } \\
\text { acenocoumarol therapy with target INR } 2 \\
\text { to } 3\end{array}$ & $\begin{array}{l}\text { Recurrent VTE: rivaroxaban, } \\
2.1 \% \text {; enoxaparin-VKA, 3.0\% }\end{array}$ & $\begin{array}{l}\text { AICH data not reported separately. } \\
\text { Bleeding in critical location: rivaroxaban, } \\
0.2 \% \text {; enoxaparin-VKA, } 0.2 \%\end{array}$ \\
\hline EINSTEIN-PE & VTE prevention & Acute PE & $\begin{array}{l}\text { Rivaroxaban } 15 \mathrm{mg} \text { BID } \times 3 \text { weeks followed } \\
\text { by } 20 \mathrm{mg} \text { daily. Standard therapy: enoxaparin } \\
1 \mathrm{mg} / \mathrm{kg} \text { BID; bridging warfarin or } \\
\text { acenocoumarol therapy with target INR } 2 \text { to } 3\end{array}$ & $\begin{array}{l}\text { Recurrent VTE: rivaroxaban, } \\
2.1 \% \text {; standard therapy, } 1.8 \%\end{array}$ & $\begin{array}{l}\text { AlCH: rivaroxaban, } 0.12 \% \text {; standard } \\
\text { therapy, } 0.50 \%\end{array}$ \\
\hline
\end{tabular}

$\overline{\mathrm{AF}}$, atrial fibrillation; AICH, anticoagulant-related intracranial hemorrhage; ARISTOTLE, Apixaban for Reduction in Stroke and Other Thromboembolic Events; BID, twice daily; CAD, coronary artery disease; CHF, congestive heart failure; DM, diabetes mellitus; DVT, deep venous thrombosis; EINSTEIN-PE, Oral Rivaroxaban Alone for the Treatment of Symptomatic Pulmonary Embolism; h/o, history of; INR, International Normalized Ratio; LVEF, left ventricular ejection fraction; NYHA, New York Heart Association; PE, pulmonary embolism; RE-COVER, Efficacy and Safety of Dabigatran Compared to Warfarin for 6 Month Treatment of Acute Symptomatic Venous Thromboembolism; RE-LY, Randomized Evaluation of Long Term Anticoagulant Therapy; ROCKET-AF, Rivaroxaban Once-daily Oral Direct Factor Xa Inhibition Compared with Vitamin K Antagonism for Prevention of Stroke and Embolism Trial in Atrial Fibrillation; SDH, subdural hematoma; TIA, transient ischemic attack; VKA, vitamin K antagonist; VTE, venous thromboembolism. 
reversal of coagulopathy in vivo as often demonstrated by the expansion of AICH even after such correction [40]. Given the emergent nature of $\mathrm{AICH}$ and their unpredictability, randomized clinical trials or even large cohort studies in this population are unlikely and recommendations regarding treatment strategies will continue to be based on case series and anecdotal experience [43].

\section{Principles and interpretation of monitoring anticoagulant therapy}

Evaluating and monitoring blood coagulation parameters is imperative after $\mathrm{AICH}$. This is particularly true when obtaining history is difficult, thus precluding knowledge of the culprit anticoagulant, information that is crucial to guide therapy. Although coagulation tests are mere surrogate markers for hemostasis, the effect of different anticoagulants on the coagulation system is important knowledge for the treating clinician to have. Some of these tests are quantitative, and others provide only qualitative information. Moreover, it is important to understand that testing techniques and their sensitivities vary widely especially with newer anticoagulants [44].

Routine and commonly used ex vivo coagulation tests are the prothrombin time (PT), INR, and activated partial thromboplastin time (aPTT); the thrombin time, ecarin clotting time, activated clotting time and endogenous thrombin potential are also available, albeit less widely. The plasma factors responsible for different coagulation assays and their alteration with oral anticoagulants are presented in Table 3 [45,46]. In patients with ongoing hemorrhage, the PT is preferred over the aPTT for the estimation of coagulation factor levels, because the results are quickly available, it offers a good correlation with average factor concentrations and response to plasma replacement, and there is no interference with nonspecific lupus anticoagulant inhibitors, elevated factor VIII, and heparin contamination [47]. The modified thrombin time (also commercially known as the HEMOCLOT thrombin time assay; Aniara, West Chester, OH, USA) and ecarin clotting time are the best tests for measuring the anticoagulant effect of dabigatran [48]. A normal thrombin time would exclude clinically significant dabigatran in systemic circulation. Although anti-factor IIa level testing is available at present, not enough information on its characteristics is known such as linearity for and responsiveness in patients on dabigatran. To the contrary, the anti-factor Xa level has good correlation with rivaroxaban/apixaban activity. The recommended test to measure the anticoagulant effect of rivaroxaban is the PT (using reagent Neoplastin Plus; ; Diagnostica Stago, Asnières-sur-Seine, France) and anti-factor Xa assay. Dabigatran and rivaroxaban drug levels can be used as surrogate markers to assess the need for anticoagulation reversal, but they are also not widely available [48-50].

Both warfarin and heparin have good linear correlation with the PT/INR and the aPTT respectively, but the utility of the traditional coagulation profile testing is questioned with the advent of newer anticoagulants (see Table 3). Viscoelastic assays that measure whole blood coagulation and provide a dynamic coagulation profile, such as thromboelastography and rotational thromboelastometry, are being increasingly used to provide rapid assessment of hemostasis [51]. These assays measure the increasing viscoelasticity of blood as it clots, which is proportional to clotting factors and platelet count/function [52]. Their advantages are a rapid turnaround time, and the detection of fibrinolysis. Clinical situations where viscoelastic assays

Table 3 Interpretation of coagulation tests with US Food and Drug Administration approved oral anticoagulants

\begin{tabular}{|c|c|c|c|c|c|}
\hline $\begin{array}{l}\text { Coagulation } \\
\text { test }\end{array}$ & $\begin{array}{l}\text { Factors } \\
\text { evaluated }\end{array}$ & $\begin{array}{l}\text { Interpretation with } \\
\text { dabigatran }\end{array}$ & $\begin{array}{l}\text { Interpretation with } \\
\text { apixaban }\end{array}$ & $\begin{array}{l}\text { Interpretation with } \\
\text { rivaroxaban }\end{array}$ & $\begin{array}{l}\text { Interpretation with } \\
\text { warfarin }\end{array}$ \\
\hline$\overline{\mathrm{PT}}$ & $\begin{array}{l}\text { Factors II, } \\
\text { V, VII, X, } \\
\text { fibrinogen }\end{array}$ & $\begin{array}{l}\text { Linear and dose dependent } \\
\text { prolongation; at therapeutic } \\
\text { range prolongs } 1.2 \text { times } \\
\text { the basal value }\end{array}$ & $\begin{array}{l}\text { Prolonged but not well } \\
\text { studied or standardized }\end{array}$ & $\begin{array}{l}\text { Linear and dose dependent } \\
\text { prolongation; at therapeutic } \\
\text { range prolongs } 1.5 \text { times the } \\
\text { basal value }\end{array}$ & Prolonged \\
\hline $\mathrm{aPT}$ & $\begin{array}{l}\text { Factors II, } \\
\text { V, VIII, IX, X, } \\
\text { fibrinogen }\end{array}$ & $\begin{array}{l}\text { Qualitative; prolongation dose } \\
\text { dependent but not linear; at } \\
\text { therapeutic range prolongs } \\
2.5 \text { times the basal value }\end{array}$ & $\begin{array}{l}\text { Prolonged but not well } \\
\text { studied or standardized }\end{array}$ & $\begin{array}{l}\text { Linear and dose dependent } \\
\text { prolongation; at therapeutic } \\
\text { range prolongs } 1.5 \text { times the } \\
\text { basal value; not as sensitive as PT }\end{array}$ & May be prolonged \\
\hline$\Pi \mathrm{T}$ & Fibrinogen & $\begin{array}{l}\text { Linear and dose dependent } \\
\text { prolongation; but prolongation } \\
\text { may be excessive and requires } \\
\text { dilution of the plasma samples }\end{array}$ & Data not available & Not affected & Not affected \\
\hline $\mathrm{ECT}$ & Factor II & $\begin{array}{l}\text { Linear and dose dependent } \\
\text { prolongation; at therapeutic } \\
\text { range prolongs three times } \\
\text { the basal value }\end{array}$ & NA & NA & NA \\
\hline ETP & Factor II & $\begin{array}{l}\text { Decreased - concentration } \\
\text { dependent }\end{array}$ & $\begin{array}{l}\text { Decreased - concentration } \\
\text { dependent }\end{array}$ & $\begin{array}{l}\text { Decreased - concentration } \\
\text { dependent }\end{array}$ & NA \\
\hline
\end{tabular}

aPTT, activated partial thromboplastin time; ECT, ecarin clotting time; ETP, endogenous thrombin potential (thrombin generation assay); NA, not applicable; PT, prothrombin time; $\Pi$, thrombin time. 
have been used to evaluate hemostasis include trauma resuscitation [53], during cardiopulmonary bypass [54] and $\mathrm{AICH}$ [55]. One study reported dose-dependent shortening of the clot-lysis time in the presence of dabigatran [56]. These laboratory tests might hold promise in the near future, although further studies and experience are needed.

\section{Reversal of anticoagulation}

Most authorities consider rapid and adequate reversal of anticoagulation as the cornerstone of therapy in $\mathrm{AICH}$, despite the lack of evidence showing that correction of coagulopathy reduces the incidence of hematoma growth or improves outcome [40]. In certain situations, however such as the presence of a mechanical valve, INR $<3$, small hemorrhage, or no surgical intervention needed - some authorities advocate holding warfarin without actively reversing coagulopathy [57]. Antidotes specific to each anticoagulant are presented in Table 1. Although warfarin remains the most commonly used oral anticoagulant, newer agents are gaining popularity. The exact mechanism of the occurrence of WRICH remains speculative, but potentially involves a local vasculopathy and/or systemic factors (for example, higher prevalence of the apolipoprotein $\mathrm{E} \varepsilon 2$ allele in patients with WRICH) $[11,58]$. Preventative measures to mitigate WRICH could therefore be relatively inefficient, and the onus is on rapid coagulopathy reversal [59]. The same probably holds true for AICH related to newer anticoagulants. Hence, the first step in any $\mathrm{AICH}$ is to discontinue the offending drug, administer an antidote (if available) and monitor adequate reversal of anticoagulation. In the case of warfarin, theoretically adequate hemostasis is restored at an INR of $\sim 1.5$ since adequate quantities of the factors needed for ex vivo coagulation are restored. However, an optimal INR value is unknown. Unfortunately, parameters for adequate reversal with newer anticoagulants are yet to be defined. Despite concern among physicians for reversing anticoagulation in a prothrombotic state, available evidence with WRICH, albeit meager, supports correcting the coagulopathy in such cases [59-61].

\section{Vitamin K}

Vitamin K 5 to $10 \mathrm{mg}$ intravenously by slow infusion over 30 minutes is administered to all patients with WRICH. Anaphylactic reactions are uncommon, and are mitigated by a slow infusion rate. The subcutaneous route for the administration of vitamin $\mathrm{K}$ is less effective because of erratic absorption, and the enteral route provides slow absorption although it has an equivalent bioavailability to the intravenous route [62]. The action of vitamin $\mathrm{K}$ is slow; it takes 6 to 24 hours to replenish adequate concentrations of factors II, VII, IX and X and to restore hemostasis $[63,64]$. This warrants the administration of fresh frozen plasma (FFP), prothrombin complex concentrate (PCC) and/or recombinant activated factor VII (rFVIIa) to rapidly replenish deficient factors. One should note that these agents have a short half-life, and are practically used as bridging therapy until vitamin $\mathrm{K}$ becomes effective.

\section{Fresh frozen plasma}

FFP contains all coagulation factors and is the most commonly used reversal agent in the USA due to its wide availability and physicians' familiarity with it. The recommended dose is anywhere between 10 and $40 \mathrm{ml} / \mathrm{kg}$ [12,64]; in clinical practice, however, FFP is commonly under-dosed for fear of volume overload. Allergic reactions, possible transmission of infectious diseases, transfusion-related acute lung injury [65] and, most importantly, a time lag to administration (due to thawing, cross-matching, prolonged infusion time) have sparked interest in a more optimal way to replete factors. Lee and colleagues reviewed records of 45 patients with WRICH treated with FFP [66]. The median time from door to INR normalization was 30 hours (14 to 49.5 hours), with four patients' hematomas enlarging after normalization. The disadvantages of using FFP can be mitigated by procurement of male donors to minimize transfusion-related acute lung injury or of universal $(\mathrm{AB}$ group) donors, and by using liquid plasma - plasma that is never frozen, thus bypassing the thawing process [67].

\section{Prothrombin complex concentrate}

Commonly available PCCs contain varying combinations and concentrations of factor II, VII, IX and X, protein C, protein $\mathrm{S}$ and protein $\mathrm{Z}$. Some contain heparin and antithrombin to reduce thrombogenic potency. PCCs are prepared from virally inactivated plasma, pooled from several donors [43]. The concentrates come in two forms: one containing the inactivated form of coagulation factors, and another containing the activated form, such as FEIBA $^{\text {тm }}$ (Baxter, Deerfield, IL, USA).

Inactivated four-factor PCCs are available in Europe and Australia. Until recently, only three-factor PCCs (factor II, IX and X) have been used in the USA. Kcentra ${ }^{\text {тм }}$ (CSL Behring, King of Prussia, PA, USA) is the first inactivated four-factor PCC approved by the US Food and Drug Administration to correct warfarin-related coagulopathy. The lack of comparative data on the efficacy of the three-factor versus four-factor PCCs makes it difficult to recommend one over the other [43], but the theoretical disadvantage of three-factor PCC led clinicians to supplement it with either FFP or rFVIIa. In clinical practice, PCCs are dosed based on factor IX content in a given preparation. The half-lives of the component factors II, VII, IX, and X are 60 hours, 4 to 6 hours, 17 to 24 hours, and 31 hours, respectively [68]. The dose varies between 25 and 100 units $/ \mathrm{kg}$, depending on the degree of INR derangement, and is infused, following reconstitution, at a rate of 100 units/minute $[69,70]$. The efficacy and safety of four-factor 
PCC as compared with FFP were demonstrated in a recently reported randomized trial that showed faster repletion of coagulation factors and similar adverse effect profile in either cohort [71].

FEIBA $^{\text {tux }}$ is an anti-inhibitor coagulant complex that is US Food and Drug Administration approved for use in hemophiliacs. The complex has been used off-label in WRICH [72]. The recommended dose of FEIBA ${ }^{\mathrm{mt}}$ is 500 to 1,000 units, and the infusion rate should not exceed 2 units $/ \mathrm{kg} /$ minute. The INR and fibrinogen should be checked 30 minutes after the end of infusion, and the dose may need to be repeated. Cryoprecipitate may be needed if the fibrinogen concentration is less than $100 \mathrm{mg} / \mathrm{dl}$. Overcorrection of INR is possible and could lead to thrombotic complications such as superficial thrombophlebitis, arterial or venous thrombosis and disseminated intravascular coagulation. Such complications are mostly dose related and their incidence in warfarin reversal is low [59]. Moreover, these adversities could be partly due to the underlying primary disease process [71,73,74]. An important factor that limits the availability of PCCs is their prohibitive cost [69], although a recent analysis suggested that they might be more cost-effective than FFP for warfarin reversal after life-threatening hemorrhages such as ICH [75].

Studies have demonstrated rapid and effective reversal of the coagulopathy but PCC efficacy is still speculative in the setting of WRICH [76,77]. In a study of 55 patients with WRICH, 31 of whom were treated with PCC, there was faster INR correction and reduction of hematoma growth at 24 hours [76]. Conversely, in another study of 141 patients there was ICH expansion in $45.5 \%$ of patients, despite correction of coagulopathy; in-hospital mortality was $42.3 \%$ [40]. A retrospective study comparing FFP and PCC for the reversal of warfarin's effect in WRICH did not demonstrate a significant difference in 30-day mortality [78]. An ongoing randomized control study is set to shed more light on this question [79]. In clinical practice, hemorrhages associated with the use of newer anticoagulants (dabigatran, rivaroxaban, and apixaban) are also managed with infusion of PCCs (25 to 50 units $/ \mathrm{kg}$ ) [80]. Both four-factor PCC and FEIBA ${ }^{\text {su }}$ (80 units $/ \mathrm{kg}$ ) have been demonstrated to increase thrombin generation in healthy volunteers on dabigatran and rivaroxaban $[45,81]$.

\section{Recombinant activated factor VII}

rFVIIa is a US Food and Drug Administration-approved treatment for congenital factor VII deficiency and hemophiliacs with inhibitors to factor VIII. This treatment has been used to correct coagulopathy associated with warfarin [82]. rFVIIa has a dual mechanism of action that involves initiating coagulation via the tissue factor and factor VIIa pathway and direct platelet activation resulting in a thrombin burst [83]. Given its short half-life (3 to 4 hours), INR reversal after rFVIIa dosing is transient, and vitamin $\mathrm{K}$ and
PCC/FFP should be used concomitantly. Lower doses of 10 to $40 \mu \mathrm{g} / \mathrm{kg}$ are associated with a lower incidence of thrombotic complications $[84,85]$. Although INR is corrected rapidly using rFVIIa, it may simply reflect the ex vivo effect of factor VIIa on the PT assay and may not always correlate with clinical hemostasis $[86,87]$. This is also reflected in the ex vivo assays where rFVIIa has been shown to reverse INR in patients on warfarin with minimal effect on aPTT and bleeding time [88]. rFVIIa is effective in reversal of the anticoagulant effect of fondaparinux in healthy volunteers [89]. Its effectiveness, however, in fondaparinux-related ICH has not yet been demonstrated [80]. Administration of rFVIIa $(120 \mu \mathrm{g} / \mathrm{kg})$ in healthy volunteers on dabigatran and rivaroxaban did not correct thrombin generation tests [81]. The long-term clinical impact of rFVIIa in patients with AICH remains to be tested in prospective studies.

\section{Protamine}

For symptomatic ICH with supratherapeutic aPTT associated with UFH, the infusion should be stopped and residual drug reversed using intravenous protamine sulfate at a ratio of $1 \mathrm{mg}$ protamine per 100 units of UFH that was infused over the preceding 3 hours. Hemorrhagic conversion remains a threat up to 48 hours following reversal. Caution should be exercised by managing blood pressure [90], and the aPTT should be followed to monitor heparin neutralization. Side effects of protamine include hypotension, bradycardia, and anaphylactoid reactions. A paradoxical anticoagulant effect can be minimized by infusing protamine slowly, over 3 minutes, and avoiding doses greater than $50 \mathrm{mg}$ at once. Protamine is less effective at neutralizing low molecular weight heparin (LMWH) because it only partially $(60 \%)$ reverses its anti-factor Xa effect $[80,91]$. A longer half-life of subcutaneously administered LMWH further contributes to their sustained effects. Evidence-based guidelines on LMWH reversal is lacking. Following the manufacturer's recommendations, $1 \mathrm{mg}$ protamine should be administered for every $1 \mathrm{mg}$ enoxaparin (Sanofi-Aventis, Bridgewater, NJ, USA), and $1 \mathrm{mg}$ protamine for every 100 anti-Xa IU dalteparin (Eisai Co. Ltd, Tokyo, Japan) or tinzaparin (LEO Pharmaceutical Products, Ballerup, Denmark) that was administered in the preceding 8 hours. If bleeding persists, an additional half-dose of protamine is recommended $[80,91]$.

\section{Antifibrinolytics}

Tranexamic acid is an antifibrinolytic agent used for prevention of re-rupture of cerebral aneurysm after subarachnoid hemorrhage. Long-term use of tranexamic acid has been associated with hydrocephalus, thrombosis and delayed cerebral ischemia in this patient population [92]. Concomitant blood pressure reduction and rapid infusion of tranexamic acid has been shown to be associated with less frequent hematoma expansion in spontaneous ICH not 
related to anticoagulant use [93]. Animal data on hemostatic therapy with tranexamic acid in WRICH demonstrated lower efficacy as compared with PCC and rFVIIa and worsening perihematomal edema [94]. Since no antidote is currently available for clinical use in dabigatranrelated major bleeding, some authorities recommend administration of $1 \mathrm{~g}$ tranexamic acid [95]. In addition, there is anecdotal experience of its use in a Jehovah's Witness patient after post-tissue plasminogen activator-related ICH to prevent hemorrhage expansion [96].

\section{Special considerations with newer oral anticoagulants}

To date, there are no specific antidotes available for clinical use to reverse the anticoagulant effect of newer oral agents such as dabigatran, apixaban, and rivaroxaban. Candidate antidotes for dabigatran and factor Xa inhibitors have demonstrated effectiveness in preclinical studies [97,98]. The proposed antidote for dabigatran is the antibody aDabi-Fab that achieves an affinity for dabigatran 350 times stronger than its affinity for thrombin. aDabi-Fab supposedly has no prothrombotic effect [98]. The antidote for factor Xa inhibitors could have wider applicability in reversing both oral and parenteral agents, including LMWH and fondaparinux. This antidote (PRT064445) reversed the inhibition of factor Xa by direct factor Xa inhibitors and corrected the prolongation of ex vivo clotting times in a dose-dependent fashion. PRT064445 restored hemostasis deranged by rivaroxaban in a rabbit model of liver laceration [97]. In rats, the antidote dose-dependently and completely corrected the increased blood loss caused by enoxaparin and fondaparinux [97].

Until specific antidotes are available for clinical use, the goal of treatment for AICH related to newer anticoagulants is to restore coagulation by thrombin generation and to overwhelm the effects of these agents with nonactivated four-factor PCC, FEIBA ${ }^{\text {m }}$ or rFVIIa $[99,100]$. Other measures may include prevention of absorption by administering activated charcoal for recent ingestion and hemodialysis or hemoperfusion [99]. The efficacy of prompt administration of activated charcoal has been demonstrated for dabigatran with in vitro models [99] and for rivaroxaban and apixaban with in vivo animal models [101,102]. In patients taking dabigatran and undergoing hemodialysis, there was an $85 \%$ reduction in plasma level at 60 minutes with charcoal hemoperfusion [103,104]. Rivaroxaban is unlikely to be dialyzable due to its high protein binding, although it may theoretically be eliminated via plasma exchange. In emergency situations such as $\mathrm{AICH}$, however, neither hemodialysis nor plasma exchange is practically feasible.

\section{Other supportive measures}

The general management of patients with AICH is outlined in recent guidelines published by the American Heart Association [105]. Here, we elaborate on the acute management of hypertension and surgical interventions, mostly relevant to intra-parenchymal bleed hemorrhages.

\section{Anti-hypertensive therapy}

In the acute phase of $\mathrm{ICH}$, elevated blood pressure is commonly encountered, with evidence linking acute hypertension to increased mortality, disability, and possibly risk of hematoma growth [106,107]. One argument against aggressive treatment of acute hypertension in $\mathrm{ICH}$, reducing perfusion around the hematoma, was counteracted by evidence from positron emission tomography studies $[108,109]$. These studies and a handful of randomized controlled trials, most notably the INTERACT-2 (Intensive Blood Pressure Reduction in Acute Cerebral Hemorrhage Trial - 2) study, showed that aggressive blood pressure lowering in ICH to treat systolic blood pressure $\leq 140 \mathrm{mmHg}$ is safe [110]. Although a difference in primary outcome was absent, there was improved morbidity among patients undergoing aggressive systolic blood pressure control. Results of an ongoing similar trial, the ATACH-II (Antihypertensive Treatment of Acute Cerebral Hemorrhage, Phase III) trial, are awaited and could add to our knowledge [111]. There remains a lack of consensus on how to manage acutely elevated blood pressure in patients with $\mathrm{AICH}$ since this population is excluded from acute ICH trials. However, extrapolating results from spontaneous $\mathrm{ICH}$ trials seems reasonable - although until such AICH trials are conducted, clinicians should use clinical judgment and manage acute hypertension on a case-by-case basis.

\section{Surgery}

The rationale to evacuate cerebral parenchymal hemorrhages is to prevent thrombin and hemoglobin degradationproduct-mediated secondary brain damage. In addition, surgical removal of blood clots alleviates pressure gradients inside the skull and restitutes normal anatomy, thus reducing or abolishing pressure on and injury to vital midline diencephalic structures. There are no studies specifically addressing the question of surgical evacuation of hematoma in $\mathrm{AICH}$, whether it is intra-parenchymal or elsewhere. In clinical practice, and for obvious reasons, reversal of coagulopathy precedes potential hematoma evacuation.

Randomized trials for spontaneous ICH go back to the early 1960s. The STICH trial (International Surgical Trial in Intracerebral Hemorrhage) randomized over 1,000 patients to early surgery (within 24 hours of randomization) or initial conservative treatment, but failed to show any clinical benefit of surgical evacuation [112]. Subgroup analysis indicating potential benefit of surgery in superficial ICH $(<1 \mathrm{~cm}$ from cerebral surface) was the basis for the recently concluded STICH II trial, in which primary intention-to-treat analysis showed a small but nonsignificant increase in the number of patients having a favorable outcome at 6 months in the early surgery group. There was 
also a suggestion of a reduction in mortality, but this finding was also nonsignificant [113].

Surgical management after traumatic brain injury leading to acute epidural or subdural hemorrhage is generally indicated if the Glasgow Coma Scale score is $\leq 8$ and there is a $5 \mathrm{~mm}$ or more shift on head computed tomography $[114,115]$. In a retrospective case series of 11 patients on oral phenprocoumon (vitamin $\mathrm{K}$ antagonist) presenting with acute subdural hemorrhage, the authors reported mortality of $45.5 \%$ at 6 months and the remaining patients were functionally independent during the same follow-up period [116]. Given the acuity and associated high morbidity and mortality of $\mathrm{AICH}$, it is difficult to systematically study surgical therapy in this subgroup of patients.

\section{Resumption of anticoagulation}

Whether and when to resume anticoagulation are other important questions that haunt clinicians managing $\mathrm{AICH}$. Again there is no straightforward and definitive answer to this dilemma. Very few data are available to guide clinicians on this important issue, and most of what we know is generated by small case series. The decision of whether to restart anticoagulation should take into consideration the recent anticoagulant-related hemorrhage and the need for anticoagulation. The evidence that supports use of anticoagulation in the disease process should be considered; and the urgency with which anticoagulation needs to be restarted and the risk of trauma/falls leading to rebleeding should also be a factor. The presence of microbleeds on brain magnetic resonance imaging might portend a higher risk of developing recurrent AICH once anticoagulation is restarted [117]. Finally, the availability of alternative approaches, in lieu of anticoagulation, to prevent progression of or complications from a thromboembolic disease process should be sought (for example, newer anticoagulants, temporary vena cava filter devices).

Claassen and colleagues reviewed medical records of 52 consecutive patients with WRICH [118]. Warfarin was restarted after a median of 10 days (range 7 to 28 days) in 23 patients; one-half of these had mechanical heart valves. During follow-up there were five cases of recurrent major bleeding in the group on warfarin, and five thromboembolic events in those not restarted on warfarin. In another retrospective study, Majeed and colleagues identified 234 patients with WRICH, 177 of whom had long-term follow-up [119]. Of these 177 patients, 59 resumed warfarin after a median of 5.6 weeks. Recurrent ICH occurred in eight patients who restarted warfarin and in 10 patients who did not. The combined risk of recurrent WRICH or ischemic stroke reached its nadir when warfarin was resumed 10 to 30 weeks after the incident WRICH.

In patients with a mechanical valve, the annual risk of systemic embolism is $4 \%$ per year, and the risk of valve thrombosis is $1.8 \%[59,64,120]$. Given the risk of hematoma expansion and subsequent high morbidity associated with WRICH, it is advisable to withhold anticoagulation in the acute phase [59]. In the 2010 version of the American Heart Association guidelines, a specific mention of time to restart anticoagulation after WRICH was omitted [105]. The European stroke initiative suggests balancing the risk of recurrent $\mathrm{ICH}$ and thromboembolism in individuals with a strong indication for anticoagulation, and reinitiating the latter 10 to 14 days after the incident WRICH [64]. Practically, resumption of anticoagulation is debated among stroke experts and most agree to restart anticoagulation in 7 to 14 days provided benefits outweigh the risk and if the hemorrhage was deep in location [121].

\section{Conclusion}

Many questions pertaining to the management of $\mathrm{AICH}$ remain unanswered. Conducting a systematic randomized trial in this subpopulation of patients is difficult. The available literature (although mostly retrospective and case series) recommends rapid correction of coagulopathy, early surgical intervention if appropriate and holding resumption of anticoagulation during the acute phase. Newer oral anticoagulants are marketed to be safe with lower incidence of $\mathrm{AICH}$ and can be potentially considered when resumption of anticoagulation is warranted. However, the lack of optimal reversal agent in case of complications may deter clinicians from using them. The development of safe and novel reversal agents for newer generation anticoagulants should thus take precedence, given their booming use and the current naivety and inexperience of the healthcare provider in managing their hemorrhagic complications. Better studies are needed to guide clinicians in appropriate management and to help prognostication. Given the overall poor functional outcome of patients with $\mathrm{ICH}$ in general, and perhaps $\mathrm{AICH}$ in particular, a need exists to explore preventative avenues. Hence, emphasis should be also placed on patient education, lifestyle and risk modification and discussion of the risk-benefit ratio before anticoagulants are prescribed.

\section{Abbreviations}

AICH: Anticoagulant-related intracranial hemorrhage; aPTT: Activated partial thromboplastin time; FFP: Fresh frozen plasma; ICH: Intracerebral hemorrhage; INR: International Normalized Ratio; LMWH: Low molecular weight heparin; PCC: Prothrombin complex concentrate; PT: Prothrombin time; rFVIla: Activated recombinant factor VII; UFH: Unfractionated heparin; WRICH: Warfarin-related intracerebral hemorrhage.

\section{Competing interests}

The authors declare that they have no competing interests.

\section{Acknowledgements}

BR would like to acknowledge the research support received from the Neurocritical Care Division, Department of Neurological Surgery at UT Southwestern Medical Center, Dallas, TX, USA during his training. 


\section{Author details}

'Division of Critical Care Neurology, Department of Neurology, The University of Oklahoma Health Sciences Center, 920 Stanton L Young Blvd, Ste 2040 Oklahoma City, OK 73104, USA. ${ }^{2}$ Department of Neurology, Washington University School of Medicine, 660 South Euclid Avenue, Box 8111, St Louis, MO 63110, USA.

\section{Published: 23 May 2014}

\section{References}

1. Guyatt GH, Norris SL, Schulman S, Hirsh J, Eckman MH, Akl EA, Crowther M, Vandvik PO, Eikelboom JW, McDonagh MS, Lewis SZ, Gutterman DD, Cook DJ, Schunermann HJ: Methodology for the development of antithrombotic therapy and prevention of thrombosis guidelines: Antithrombotic Therapy and Prevention of Thrombosis, 9th ed: American College of Chest Physicians Evidence-Based Clinical Practice Guidelines. Chest 2012, 141:53S-70S.

2. De Caterina R, Husted S, Wallentin L, Andreotti F, Arnesen H, Bachmann F, Baigent C, Huber K, Jespersen J, Kristensen SD, Lip GY, Morais J, Rasmussen LH, Siegbahn A, Vergeut FW, Weitz Jl: New oral anticoagulants in atrial fibrillation and acute coronary syndromes: ESC Working Group on Thrombosis - Task Force on Anticoagulants in Heart Disease position paper. J Am Coll Cardiol 2012, 59:1413-1425

3. De Caterina R, Husted S, Wallentin L, Andreotti F, Arnesen H, Bachmann F, Baigent C, Huber K, Jespersen J, Kristensen SD, Lip GY, Morais J, Rasmussen LH, Siegbahn A, Vergeut FW, Weitz I: General mechanisms of coagulation and targets of anticoagulants (Section I). Position Paper of the ESC Working Group on Thrombosis - Task Force on Anticoagulants in Heart Disease. Thromb Haemost 2013, 109:569-579.

4. Stroke Prevention in Atrial Fibrillation Invesitgators group: Stroke prevention in atrial fibrillation study. Final results. Circulation 1991, 84:527-539.

5. European Atrial Fibrillation Trial Study Group: Secondary prevention in non-rheumatic atrial fibrillation after transient ischaemic attack or minor stroke. EAFT (European Atrial Fibrillation Trial) Study Group. Lancet 1993 342:1255-1262.

6. Stafford RS, Singer DE: National patterns of warfarin use in atrial fibrillation. Arch Intern Med 1996, 156:2537-2541.

7. Go AS, Hylek EM, Phillips KA, Chang Y, Henault LE, Selby JV, Singer DE: Prevalence of diagnosed atrial fibrillation in adults: national implications for rhythm management and stroke prevention: the AnTicoagulation and Risk Factors in Atrial Fibrillation (ATRIA) Study. JAMA 2001, 285:2370-2375.

8. Flaherty ML, Kissela B, Woo D, Kleindorfer D, Alwell K, Sekar P, Moomaw CJ, Haverbusch M, Broderick JP: The increasing incidence of anticoagulantassociated intracerebral hemorrhage. Neurology 2007, 68:116-121.

9. Kase CS, Robinson RK, Stein RW, DeWitt LD, Hier DB, Harp DL, Williams JP, Caplan LR, Mohr JP: Anticoagulant-related intracerebral hemorrhage. Neurology 1985, 35:943-948.

10. Kase CS: Intracerebral hemorrhage: non-hypertensive causes. Stroke 1986, 17:590-595.

11. Hart RG, Boop BS, Anderson DC: Oral anticoagulants and intracranial hemorrhage. Facts and hypotheses. Stroke 1995, 26:1471-1477.

12. Steiner T, Rosand J, Diringer M: Intracerebral hemorrhage associated with oral anticoagulant therapy: current practices and unresolved questions. Stroke 2006, 37:256-262

13. Franke $\mathrm{CL}$, de Jonge J, van Swieten JC, Op de Coul AA, van Gijn J: Intracerebral hematomas during anticoagulant treatment. Stroke 1990, 21:726-730.

14. Wintzen $A R$, de Jonge $H$, Loeliger EA, Bots GT: The risk of intracerebral hemorrhage during oral anticoagulant treatment: a population study. Ann Neurol 1984, 16:553-558.

15. Hylek EM, Singer DE: Risk factors for intracranial hemorrhage in outpatients taking warfarin. Ann Internal Med 1994, 120:897-902.

16. Landefeld CS, Goldman L: Major bleeding in outpatients treated with warfarin: incidence and prediction by factors known at the start of outpatient therapy. Am J Med 1989, 87:144-152

17. Barron KD, Fergusson $\mathrm{G}$ : Intracranial hemorrhage as a complication of anticoagulant therapy. Neurology 1959, 9:447-455

18. Hansen ML, Sorensen R, Clausen MT, Fog-Petersen ML, Raunso J, Gadsboll N, Gislason GH, Folke F, Andersen SS, Schramm TK, Abildstrom SZ, Poulsen HE, Kober L, Torp-Pedesen C: Risk of bleeding with single, dual, or triple therapy with warfarin, aspirin, and clopidogrel in patients with atrial fibrillation. Arch Intern Med 2010, 170:1433-1441.
19. Radberg JA, Olsson JE, Radberg CT: Prognostic parameters in spontaneous intracerebral hematomas with special reference to anticoagulant treatment. Stroke 1991, 22:571-576

20. Hart RG, Pearce LA: In vivo antithrombotic effect of aspirin: dose versus nongastrointestinal bleeding. Stroke 1993, 24:138-139.

21. Smith EE, Rosand J, Knudsen KA, Hylek EM, Greenberg SM: Leukoaraiosis is associated with warfarin-related hemorrhage following ischemic stroke. Neurology 2002, 59:193-197.

22. Snyder M, Renaudin J: Intracranial hemorrhage associated with anticoagulation therapy. Surg Neurol 1977, 7:31-34.

23. The Stroke Prevention in Reversible Ischemia Trial (SPIRIT) Study Group: A randomized trial of anticoagulants versus aspirin after cerebral ischemia of presumed arterial origin. The Stroke Prevention in Reversible Ischemia Trial (SPIRIT) Study Group. Ann Neurol 1997, 42:857-865.

24. International Stroke Trial Collaborative Group: The International Stroke Trial (IST): a randomised trial of aspirin, subcutaneous heparin, both, or neither among 19435 patients with acute ischaemic stroke. International Stroke Trial Collaborative Group. Lancet 1997, 349:1569-1581.

25. The Publications Committee for the Trial of ORG 10172 in Acute Stroke Treatment (TOAST) Investigators: Low molecular weight heparinoid, ORG 10172 (danaparoid), and outcome after acute ischemic stroke: a randomized controlled trial. The Publications Committee for the Trial of ORG 10172 in Acute Stroke Treatment (TOAST) Investigators. JAMA 1998 279:1265-1272.

26. LaMonte MP, Nash ML, Wang DZ, Woolfenden AR, Schultz J, Hursting MJ, Brown PM: Argatroban anticoagulation in patients with acute ischemic stroke (ARGIS-1): a randomized, placebo-controlled safety study. Stroke 2004 35:1677-1682.

27. Hart RG, Diener HC, Yang S, Connolly SJ, Wallentin L, Reilly PA, Ezekowitz MD, Yusuf S: Intracranial hemorrhage in atrial fibrillation patients during anticoagulation with warfarin or dabigatran: the RE-LY trial. Stroke 2012, 43:1511-1517.

28. Schulman S, Kearon C, Kakkar AK, Mismetti P, Schellong S, Eriksson H, Baanstra D, Schnee J, Goldhaber SZ: Dabigatran versus warfarin in the treatment of acute venous thromboembolism. N Engl J Med 2009, 361:2342-2352.

29. Flaker GC, Eikelboom JW, Shestakovska O, Connolly SJ, Kaatz S, Budaj A, Husted S, Yusuf S, Lip GY, Hart RG: Bleeding during treatment with aspirin versus apixaban in patients with atrial fibrillation unsuitable for warfarin: the apixaban versus acetylsalicylic acid to prevent stroke in atrial fibrillation patients who have failed or are unsuitable for vitamin K antagonist treatment (AVERROES) trial. Stroke 2012, 43:3291-3297.

30. Granger CB, Alexander JH, McMurray JJ, Lopes RD, Hylek EM, Hanna M, Al-Khalidi HR, Ansell J, Atar D, Avezum A, Bahit MC, Diaz R, Easton JD, Ezekowitz JA, Flaker G, Garcia D, Geraldes M, Gersh BJ, Golitsyn S, Goto S, Hermosillo AG, Hohnloser SH, Horowitz J, Mohan P, Jansky P, Lewis BS, Lopez-Sendon JL, Pais P, Parkhomenko A, Verheugt FW, et al: Apixaban versus warfarin in patients with atrial fibrillation. N Engl J Med 2011, 365:981-992.

31. Patel MR, Mahaffey KW, Garg J, Pan G, Singer DE, Hacke W, Breithardt G, Halperin JL, Hankey GJ, Piccini JP, Becker RC, Nessel CC, Paolini JF, Berkowitz SD, Fox KA, Califf RM: Rivaroxaban versus warfarin in nonvalvular atrial fibrillation. $N$ Engl J Med 2011, 365:883-891.

32. Buller HR, Prins MH, Lensin AW, Decousus H, Jacobson BF, Minar E, Chlumsky J, Verhamme P, Wells P, Agnelli G, Cohen A, Berkowitz SD, Bounameaux H, Davidson BL, Misselwitz F, Gallus AS, Raskob GE, Schellong S, Segers A: Oral rivaroxaban for the treatment of symptomatic pulmonary embolism. N Engl J Med 2012, 366:1287-1297.

33. Wayangankar SA, Abu-Fadel MS, Aronow HD, Kennedy KF, Gupta R, Yeh RW, Gray WA, Rosenfield K, Hennebry TA: Hemorrhagic and ischemic outcomes after bivalirudin versus unfractionated heparin during carotid artery stenting: a propensity score analysis from the NCDR. Circ Cardiovasc Interv 2013, 6:131-138.

34. Flaherty ML, Haverbusch M, Sekar P, Kissela BM, Kleindorfer D, Moomaw CJ Broderick JP, Woo D: Location and outcome of anticoagulant-associated intracerebral hemorrhage. Neurocrit Care 2006, 5:197-201.

35. Rosand J, Eckman MH, Knudsen KA, Singer DE, Greenberg SM: The effect of warfarin and intensity of anticoagulation on outcome of intracerebra hemorrhage. Arch Intern Med 2004, 164:880-884

36. Sjalander A, Engstrom G, Berntorp E, Svensson P: Risk of haemorrhagic stroke in patients with oral anticoagulation compared with the general population. $J$ Intern Med 2003, 254:434-438. 
37. Flaherty ML, Tao $H$, Haverbusch $M$, Sekar $P$, Kleindorfer $D$, Kissela $B$, Khatri $P$, Stettler B, Adeoye O, Moomaw CJ, Broderick JP, Woo D: Warfarin use leads to larger intracerebral hematomas. Neurology 2008, 71:1084-1089.

38. Flaherty ML: Anticoagulant-associated intracerebral hemorrhage. Semin Neurol 2010, 30:565-572.

39. Cucchiara B, Messe S, Sansing L, Kasner S, Lyden P: Hematoma growth in oral anticoagulant related intracerebral hemorrhage. Stroke 2008, 39:2993-2996.

40. Dowlatshahi D, Butcher KS, Asdaghi N, Nahirniak S, Bernbaum ML, Giulivi A, Wasserman JK, Poon MC, Coutts SB: Poor prognosis in warfarin-associated intracranial hemorrhage despite anticoagulation reversal. Stroke 2012, 43:1812-1817

41. Pengo V, Crippa L, Falanga A, Finazzi G, Marongiu F, Moia M, Palareti G, Poli D, Testa S, Tiraferri E, Tosetto A, Tripodi A, Siragusa S, Manotti C: Phase III studies on novel oral anticoagulants for stroke prevention in atrial fibrillation: a look beyond the excellent results. J Thromb Haemost 2012, 10:1979-1987.

42. Levy JH, Dutton RP, Hemphill JC 3rd, Shander A, Cooper D, Paidas MJ, Kessler CM, Holcomb JB, Lawson JH: Multidisciplinary approach to the challenge of hemostasis. Anesth Analg 2010, 110:354-364.

43. Crowther MA, Warkentin TE: Bleeding risk and the management of bleeding complications in patients undergoing anticoagulant therapy: focus on new anticoagulant agents. Blood 2008, 111:4871-4879.

44. Steiner T, Bohm M, Dichgans M, Diener HC, Ell C, Endres M, Epple C, Grond M, Laufs U, Nickenig G, Reiss H, Rother J, Schellinger PD, Spannagl M, Veltkamp R: Recommendations for the emergency management of complications associated with the new direct oral anticoagulants (DOACs), apixaban, dabigatran and rivaroxaban. Clin Res Cardiol 2013, 102:399-412.

45. Eerenberg ES, Kamphuisen PW, Sijpkens MK, Meijers JC, Buller HR, Levi M: Reversal of rivaroxaban and dabigatran by prothrombin complex concentrate: a randomized, placebo-controlled, crossover study in healthy subjects. Circulation 2011, 124:1573-1579.

46. van Ryn J, Stangier J, Haertter S, Liesenfeld KH, Wienen W, Feuring M, Clemens A: Dabigatran etexilate - a novel, reversible, oral direct thrombin inhibitor: interpretation of coagulation assays and reversal of anticoagulant activity. Thromb Haemost 2010, 103:1116-1127.

47. Yuan S, Ferrell C, Chandler WL: Comparing the prothrombin time INR versus the APTT to evaluate the coagulopathy of acute trauma. Thromb Res 2007, 120:29-37.

48. Tripodi A: The laboratory and the new oral anticoagulants. Clin Chem 2013, 59:353-362.

49. Samama MM, Martinoli JL, LeFlem L, Guinet C, Plu-Bureau G, Depasse F, Perzborn E: Assessment of laboratory assays to measure rivaroxaban - an oral, direct factor Xa inhibitor. Thromb Haemost 2010, 103:815-825.

50. Stangier J, Rathgen K, Stahle H, Gansser D, Roth W: The pharmacokinetics, pharmacodynamics and tolerability of dabigatran etexilate, a new oral direct thrombin inhibitor, in healthy male subjects. Br J Clin Pharmacol 2007, 64:292-303.

51. Chandler WL: Emergency assessment of hemostasis in the bleeding patient. Int J Lab Hematol 2013, 35:339-343.

52. Chandler WL: The thromboelastography and the thromboelastograph technique. Semin Thromb Hemost 1995, 21:1-6.

53. Cotton BA, Faz G, Hatch QM, Radwan ZA, Podbielski J, Wade C, Kozar RA Holcomb JB: Rapid thrombelastography delivers real-time results that predict transfusion within 1 hour of admission. J Trauma 2011, 71:407-414. discussion 414-417.

54. Gorlinger K, Dirkmann D, Hanke AA, Kamler M, Kottenberg E, Thielmann M, Jakob $H$, Peters J: First-line therapy with coagulation factor concentrates combined with point-of-care coagulation testing is associated with decreased allogeneic blood transfusion in cardiovascular surgery: a retrospective, single-center cohort study. Anesthesiology 2011, 115:1179-1191.

55. Neyens R, Bohm N, Cearley M, Andrews C, Chalela J: Dabigatran-associated subdural hemorrhage: using thromboelastography (TEG) to guide decision-making. J Thromb Thrombolysis 2014, 37:80-83.

56. Ammollo CT, Semeraro F, Incampo F, Semeraro N, Colucci M: Dabigatran enhances clot susceptibility to fibrinolysis by mechanisms dependent on and independent of thrombin-activatable fibrinolysis inhibitor. J Thromb Haemost 2010, 8:790-798.

57. Selim MH, Molina CA: The role of hemostatic therapy in anticoagulationassociated intracerebral hemorrhage: intuition versus evidence. Stroke 2012, 43:2539-2540.
58. Rosand J, Hylek EM, O'Donnell HC, Greenberg SM: Warfarin-associated hemorrhage and cerebral amyloid angiopathy: a genetic and pathologic study. Neurology 2000, 55:947-951.

59. Appelboam R, Thomas EO: Warfarin and intracranial haemorrhage. Blood Rev 2009, 23:1-9.

60. Punthakee $X$, Doobay J, Anand SS: Oral-anticoagulant-related intracerebral hemorrhage. Thromb Res 2002, 108:31-36.

61. Wijdicks EF, Schievink WI, Brown RD, Mullany CJ: The dilemma of discontinuation of anticoagulation therapy for patients with intracranial hemorrhage and mechanical heart valves. Neurosurgery 1998, 42:769-773.

62. Watson HG, Baglin T, Laidlaw SL, Makris M, Preston FE: A comparison of the efficacy and rate of response to oral and intravenous Vitamin $\mathrm{K}$ in reversal of over-anticoagulation with warfarin. Br J Haematol 2001, 115:145-149.

63. Ansell J, Hirsh J, Hylek E, Jacobson A, Crowther M, Palareti G: Pharmacology and management of the vitamin K antagonists: American College of Chest Physicians Evidence-Based Clinical Practice Guidelines (8th edition). Chest 2008, 133:160S-1985.

64. Steiner T, Kaste M, Forsting M, Mendelow D, Kwiecinski H, Szikora I, Juvela S, Marchel A, Chapot R, Cognard C, Unterberg A, Hacke W: Recommendations for the management of intracranial haemorrhage - part I: spontaneous intracerebral haemorrhage. The European Stroke Initiative Writing Committee and the Writing Committee for the EUSI Executive Committee. Cerebrovasc Dis 2006, 22:294-316.

65. Hellstern P, Muntean W, Schramm W, Seifried E, Solheim BG: Practical guidelines for the clinical use of plasma. Thromb Res 2002, 107:\$53-S57.

66. Lee SB, Manno EM, Layton KF, Wijdicks EF: Progression of warfarinassociated intracerebral hemorrhage after INR normalization with FFP. Neurology 2006, 67:1272-1274.

67. Goodnough LT, Shander A: How I treat warfarin-associated coagulopathy in patients with intracerebral hemorrhage. Blood 2011, 117:6091-6099.

68. Ostermann $\mathrm{H}$, Haertel S, Knaub S, Kalina U, Jung K, Pabinger I: Pharmacokinetics of Beriplex $\mathrm{P} / \mathrm{N}$ prothrombin complex concentrate in healthy volunteers. Thromb Haemost 2007, 98:790-797.

69. Hanley JP: Warfarin reversal. J Clin Pathol 2004, 57:1132-1139.

70. Schulman S: Clinical practice. Care of patients receiving long-term anticoagulant therapy. N Engl J Med 2003, 349:675-683.

71. Sarode R, Milling TJ Jr, Refaai MA, Mangione A, Schneider A, Durn BL, Goldstein JN: Efficacy and safety of a 4-factor prothrombin complex concentrate in patients on vitamin $\mathrm{K}$ antagonists presenting with major bleeding: a randomized, plasma-controlled, phase IIlb study. Circulation 2013, 128:1234-1243.

72. Wojcik C, Schymik ML, Cure EG: Activated prothrombin complex concentrate factor VIII inhibitor bypassing activity (FEIBA) for the reversal of warfarin-induced coagulopathy. Int J Emerg Med 2009, 2:217-225.

73. Sorensen B, Spahn DR, Innerhofer P, Spannagl M, Rossaint R: Clinical review: Prothrombin complex concentrates - evaluation of safety and thrombogenicity. Crit Care 2011, 15:201.

74. Dentali F, Marchesi C, Pierfranceschi MG, Crowther M, Garcia D, Hylek E, Witt DM, Clark NP, Squizzato A, Imberti D, Ageno W: Safety of prothrombin complex concentrates for rapid anticoagulation reversal of vitamin $\mathrm{K}$ antagonists. A meta-analysis. Thromb Haemost 2011, 106:429-438.

75. Guest JF, Watson HG, Limaye S: Modeling the cost-effectiveness of prothrombin complex concentrate compared with fresh frozen plasma in emergency warfarin reversal in the United kingdom. Clin Ther 2010, 32:2478-2493

76. Huttner HB, Schellinger PD, Hartmann M, Kohrmann M, Juettler E, Wikner J, Mueller S, Meyding-Lamade U, Strobl R, Mansmann U, Schwab S, Steiner T: Hematoma growth and outcome in treated neurocritical care patients with intracerebral hemorrhage related to oral anticoagulant therapy: comparison of acute treatment strategies using vitamin $\mathrm{K}$, fresh frozen plasma, and prothrombin complex concentrates. Stroke 2006, 37:1465-1470.

77. Makris M, Greaves M, Phillips WS, Kitchen S, Rosendaal FR, Preston EF: Emergency oral anticoagulant reversal: the relative efficacy of infusions of fresh frozen plasma and clotting factor concentrate on correction of the coagulopathy. Thromb Haemost 1997, 77:477-480.

78. Sjoblom L, Hardemark HG, Lindgren A, Norrving B, Fahlen M, Samuelsson M, Stigendal L, Stockelberg D, Taghavi A, Wallrup L, Wallvik J: Management and prognostic features of intracerebral hemorrhage during anticoagulant therapy: a Swedish multicenter study. Stroke 2001, $32: 2567-2574$ 
79. Steiner T, Freiberger A, Griebe M, Husing J, Ivandic B, Kollmar R, Pfefferkorn T, Wartenberg KE, Weimar C, Hennerici M, Poli S: International normalised ratio normalisation in patients with coumarin-related intracranial haemorrhages - the INCH trial: a randomised controlled multicentre trial to compare safety and preliminary efficacy of fresh frozen plasma and prothrombin complex - study design and protocol. Int J Stroke 2011 6:271-277.

80. Tawil IS, DB, Duprey J: Emergency management of coagulopathy in acute intracranial hemorrhage. EM Crit Care 2012, 2:1-20.

81. Marlu R, Hodaj E, Paris A, Albaladejo P, Cracowski JL, Pernod G: Effect of non-specific reversal agents on anticoagulant activity of dabigatran and rivaroxaban: a randomised crossover ex vivo study in healthy volunteers. Thromb Haemost 2012, 108:217-224.

82. Deveras RA, Kessler CM: Reversal of warfarin-induced excessive anticoagulation with recombinant human factor Vlla concentrate. Ann Internal Med 2002 , 137:884-888

83. Hedner U, Erhardtsen E: Potential role of recombinant factor VIla as a hemostatic agent. Clin Adv Hematol Oncol 2003, 1:112-119.

84. Dager WE, King JH, Regalia RC, Williamson D, Gosselin RC, White RH, Tharratt RS, Albertson TE: Reversal of elevated international normalized ratios and bleeding with low-dose recombinant activated factor VII in patients receiving warfarin. Pharmacotherapy 2006, 26:1091-1098.

85. Sorensen B, Johansen P, Nielsen GL, Sorensen JC, Ingerslev J: Reversal of the International Normalized Ratio with recombinant activated factor VII in central nervous system bleeding during warfarin thromboprophylaxis: clinical and biochemical aspects. Blood Coagul Fibrinolysis 2003, 14:469-477.

86. Gabriel DA, Carr M, Roberts HR: Monitoring coagulation and the clinical effects of recombinant factor VIla. Semin Hematol 2004, 41:20-24.

87. Levi M, Bijsterveld NR, Keller TT: Recombinant factor VIla as an antidote for anticoagulant treatment. Semin Hematol 2004, 41:65-69.

88. Tanaka KA, Szlam F, Dickneite G, Levy JH: Effects of prothrombin complex concentrate and recombinant activated factor VII on vitamin $\mathrm{K}$ antagonist induced anticoagulation. Thromb Res 2008, 122:117-123.

89. Bijsterveld NR, Moons AH, Boekholdt SM, van Aken BE, Fennema H, Peters RJ, Meijers JC, Buller HR, Levi M: Ability of recombinant factor VIla to reverse the anticoagulant effect of the pentasaccharide fondaparinux in healthy volunteers. Circulation 2002, 106:2550-2554

90. Kase CS, Greenberg SM, Mohr JP, Caplan LR: Intracerebral Hemorrhage. In Stroke: Pathophysiology, Diagnosis, and Management. Edited by Mohr JP. Philadelphia, PA: Elsevier Saunders; 2011:531-588.

91. Holst J, Lindblad B, Bergqvist D, Garre K, Nielsen H, Hedner U, Ostergaard PB: Protamine neutralization of intravenous and subcutaneous low-molecularweight heparin (tinzaparin, Logiparin). An experimental investigation in healthy volunteers. Blood Coagul Fibrinolysis 1994, 5:795-803.

92. Liu-DeRyke $X$, Rhoney D: Hemostatic therapy for the treatment of intracranial hemorrhage. Pharmacotherapy 2008, 28:485-495.

93. Sorimachi T, Fujii Y, Morita K, Tanaka R: Rapid administration of antifibrinolytics and strict blood pressure control for intracerebral hemorrhage. Neurosurgery 2005, 57:837-844

94. Illanes S, Zhou W, Schwarting S, Heiland S, Veltkamp R: Comparative effectiveness of hemostatic therapy in experimental warfarin-associated intracerebral hemorrhage. Stroke 2011, 42:191-195.

95. Alikhan R, Rayment R, Keeling D, Baglin T, Benson G, Green L, Marshall S, Patel R, Pavord S, Rose $P$, Tait C: The acute management of haemorrhage, surgery and overdose in patients receiving dabigatran. Emerg Med J 2014, 31:163-168.

96. French KF, White J, Hoesch RE: Treatment of intracerebral hemorrhage with tranexamic acid after thrombolysis with tissue plasminogen activator. Neurocrit Care 2012, 17:107-111.

97. Lu G, Deguzman FR, Hollenbach SJ, Karbarz MJ, Abe K, Lee G, Luan P, Hutchaleelaha A, Inagaki M, Conley PB, Phillips DR, Sinha U: A specific antidote for reversal of anticoagulation by direct and indirect inhibitors of coagulation factor Xa. Nat Med 2013, 19:446-451.

98. Schiele F, van Ryn J, Canada K, Newsome C, Sepulveda E, Park J, Nar H, Litzenburger T: A specific antidote for dabigatran: functional and structural characterization. Blood 2013, 121:3554-3562.

99. Kaatz S, Crowther M: Reversal of target-specific oral anticoagulants. Thromb Thrombolysis 2013, 36:195-202.

100. Khoo TL, Weatherburn C, Kershaw G, Reddel CJ, Curnow J, Dunkley S: The use of FEIBA(R) in the correction of coagulation abnormalities induced by dabigatran. Int J Lab Hematol 2013, 35:222-224.
101. Johnson \& Johnson Pharmaceutical Research \& Development LLC: Advisory Committee Briefing Book: Rivaroxaban for the Prophylaxis of Deep Vein Thrombosis (DVT) and Pulmonary Embolism (PE) in Patients Undergoing Hip or Knee Replacement Surgery. San Diego, CA: Johnson \& Johnson Pharmaceutical Research \& Development, L.L.C; 2009

102. Eliquis - Apixaban. http://www.ema.europa.eu/ema/index.jsp?curl=pages/ medicines/human/medicines/002148/human_med_001449. jsp\&murl=menus/medicines/medicines.jsp\&mid=WC0b01ac058001d125.

103. Khadzhynov D, Wagner F, Formella S, Wiegert E, Moschetti V, Slowinski T, Neumayer HH, Liesenfeld KH, Lehr T, Hartter S, Friedman J, Peters H, Clemens A: Effective elimination of dabigatran by haemodialysis. A phase I single-centre study in patients with end-stage renal disease. Thromb Haemost 2013, 109:596-605.

104. Van Ryn J, Neubauer M, Flieg R, Krause B, Storr M, Hauel N, Priepke H, Clemens A: Successful removal of dabigatran in flowing blood with an activated charcoal hemoperfusion column in an in vitro test system. Haematologica 2010, 95:293.

105. Morgenstern LB, Hemphill JC 3rd, Anderson C, Becker K, Broderick JP, Connolly ES Jr, Greenberg SM, Huang JN, MacDonald RL, Messe SR, Mitchell PH, Selim M, Tamago RJ: Guidelines for the management of spontaneous intracerebral hemorrhage: a guideline for healthcare professionals from the American Heart Association/American Stroke Association. Stroke 2010, 41:2108-2129

106. Qureshi Al, Palesch YY, Martin R, Novitzke J, Cruz-Flores S, Ehtisham A, Ezzeddine MA, Goldstein JN, Hussein HM, Suri MF, Tariq N: Effect of systolic blood pressure reduction on hematoma expansion, perihematomal edema, and 3-month outcome among patients with intracerebral hemorrhage: results from the antihypertensive treatment of acute cerebral hemorrhage study. Arch Neurol 2010, 67:570-576.

107. Zhang Y, Reilly KH, Tong W, Xu T, Chen J, Bazzano LA, Qiao D, Ju Z, Chen CS, He J: Blood pressure and clinical outcome among patients with acute stroke in Inner Mongolia, China. J Hypertens 2008, 26:1446-1452.

108. Powers WJ, Zazulia AR, Videen TO, Adams RE, Yundt KD, Aiyagari V, Grubb $\mathrm{RL} J \mathrm{r}$, Diringer MN: Autoregulation of cerebral blood flow surrounding acute (6 to 22 hours) intracerebral hemorrhage. Neurology 2001, 57:18-24.

109. Zazulia AR, Diringer MN, Videen TO, Adams RE, Yundt K, Aiyagari V, Grubb RL Jr, Powers WJ: Hypoperfusion without ischemia surrounding acute intracerebral hemorrhage. J Cereb Blood Flow Metab 2001, 21:804-810.

110. Anderson CS, Heeley E, Huang Y, Wang J, Stapf C, Delcourt C, Lindley R, Robinson T, Lavados P, Neal B, Hata J, Arima H, Parsons M, Li Y, Wang J, Heritier S, Li Q, Woodward M, Simes RJ, Davis SM, Chalmers J, INTERACT2 Investigators: Rapid blood-pressure lowering in patients with acute intracerebral hemorrhage. N Engl J Med 2013, 368:2355-2365.

111. Qureshi Al, Palesch YY: Antihypertensive Treatment of Acute Cerebral Hemorrhage (ATACH) II: design, methods, and rationale. Neurocrit Care 2011, 15:559-576.

112. Mendelow AD, Gregson BA, Fernandes HM, Murray GD, Teasdale GM, Hope DT, Karimi A, Shaw MD, Barer DH: Early surgery versus initial conservative treatment in patients with spontaneous supratentorial intracerebral haematomas in the International Surgical Trial in Intracerebral Haemorrhage (STICH): a randomised trial. Lancet 2005, 365:387-397.

113. Mendelow AD, Gregson BA, Rowan EN, Murray GD, Gholkar A, Mitchell PM, STICH II Investigators: Early surgery versus initial conservative treatment in patients with spontaneous supratentorial lobar intracerebral haematomas (STICH II): a randomised trial. Lancet 2013, 382:397-408.

114. Bullock MR, Chesnut R, Ghajar J, Gordon D, Hartl R, Newell DW, Servadei F, Walters BC, Wilberger JE: Surgical management of acute subdural hematomas. Neurosurgery 2006, 58:S16-S24. discussion Si-Siv.

115. Bullock MR, Chesnut R, Ghajar J, Gordon D, Hartl R, Newell DW, Servadei F, Walters BC, Wilberger JE: Surgical management of acute epidural hematomas. Neurosurgery 2006, 58:S7-S15. discussion Si-Siv.

116. Senft C, Schuster T, Forster MT, Seifert V, Gerlach R: Management and outcome of patients with acute traumatic subdural hematomas and pre-injury oral anticoagulation therapy. Neurol Res 2009, 31:1012-1018.

117. Lee SH, Ryu WS, Roh JK: Cerebral microbleeds are a risk factor for warfarin-related intracerebral hemorrhage. Neurology 2009, 72:171-176.

118. Claassen DO, Kazemi N, Zubkov AY, Wijdicks EF, Rabinstein AA: Restarting anticoagulation therapy after warfarin-associated intracerebral hemorrhage. Arch Neurol 2008, 65:1313-1318. 
119. Majeed A, Kim YK, Roberts RS, Holmstrom M, Schulman S: Optimal timing of resumption of warfarin after intracranial hemorrhage. Stroke 2010, 41:2860-2866.

120. Cannegieter SC, Rosendaal FR, Briet E: Thromboembolic and bleeding complications in patients with mechanical heart valve prostheses. Circulation 1994, 89:635-641.

121. Steiner T: Resumption of oral anticoagulation after warfarin-associated intracerebral hemorrhage: yes. Stroke 2011, 42:3661-3662.

$10.1186 /$ cc13889

Cite this article as: Ray and Keyrouz: Management of anticoagulant-related

intracranial hemorrhage: an evidence-based review. Critical Care 2014, 18:223 